\title{
Audit of endoscopic surveillance biopsy specimens in HIV positive patients with gastrointestinal symptoms
}

S G Lim, M Cl Lipman, S Squire, D Pillay, S Gillespie, E A Sankey, A P Dhillon, M A Johnson, C A Lee, R E Pounder

\begin{abstract}
An audit of upper gastrointestinal endoscopy in HIV infected patients with gastrointestinal symptoms assessed the frequency of disease detected by endoscopy and routine laboratory analysis of surveillance biopsy specimens. Sixty nine consecutive endoscopies were performed in 59 HIV infected patients. Endoscopic biopsy specimens were taken from the lower oesophagus, gastric antrum, and third part of the duodenum for virology, histopathology, parasitology, bacteriology, and mycobacterial culture. Endoscopic appearances detected disease in $25 / 59(42.4 \%)$ patients (oesophageal candida, 14; oesophageal ulcer, 3; Kaposi's sarcoma, 4; others, 4), but only $4 / 43(9 \cdot 3 \%)$ specimens showed evidence of disease in the absence of endoscopic abnormality. Virology for cytomegalovirus (detection of early antigenic fluorescent foci and culture) was positive in $6 / 59(10.2 \%)$ patients, but parasitology and mycobacterial culture were negative in all cases. Histopathology was abnormal in 11/52 (21\%) oesophageal biopsy specimens, $13 / 47(28 \%)$ gastric biopsy specimens, and 4/65 (6\%) duodenal biopsy specimens. Abnormal findings were found predominantly in those with advanced HIV disease (CDC Stage IV) (21/33 patients (64\%)) compared with those with early HIV disease (CDC Stage II) (5/26 (19\%)). In conclusion, upper gastrointestinal endoscopy detects macroscopic disease in AIDS patients and those with low CD4 counts, but routine surveillance biopsy specimens of apparently normal bowel in early HIV disease (or where CD4 counts are greater than $\left.0.2 \times 10^{\circ} / 1\right)$ are of little value.

(Gut 1993; 34: 1429-1432)
\end{abstract}

and Pathology

E A Sankey

A P Dhillon

and Aids Unit

M Cl Lipman

S Squire

M A Johnson

and Haemophilia Centre, Royal Free Hospital and School of Medicine, London

C A Lee

Correspondence to: Dr S G Lim, University Department of Medicine, Royal Free Hospital School of Medicine, Pond Street, London NW3 2QG.

Accepted for publication 16 February 1993

The gastrointestinal tract is a major target organ for disease associated with HIV infection. Patients infected with HIV may develop diarrhoea, dysphagia, abdominal pain, or weight loss or all four. ${ }^{1-5}$ The endoscopic investigation of symptomatic HIV infected patients can prove both time consuming and expensive, particularly if large numbers of biopsy specimens are taken in a search of occult opportunistic infection. The aim of the present audit was to determine the value of surveillance biopsies during routine upper gastrointestinal endoscopy, in a group of HIV infected patients with gastrointestinal symptoms.
Methods

PATIENTS

An upper gastrointestinal endoscopy was performed in 59 consecutive HIV infected patients for a variety of clinical indications (Table I). All but four of the patients were men; the group had a median age of 35 years (range 17 to 61 ). When staged using the revised Center for Disease Control (CDC) criteria, ${ }^{6} 26$ of the patients were CDC stage II, three were CDC IV A (AIDS related complex), and 30 were CDC IV C (AIDS). Diarrhoea was defined as having more than two loose bowel actions a day for two weeks, and weight loss was defined as a greater than $10 \%$ loss of body weight.

\section{ENDOSCOPY AND BIOPSY}

Upper gastrointestinal endoscopy was performed with an IT 20, XQ 10, or XQ 20 endoscope (Olympus, Keymed, Southend-on-Sea, Essex, UK). The agreed protocol was that all abnormalities seen during the endoscopic procedure were to be biopsied for analysis by histopathology and virology, and also for mycobacterial culture. In addition, in all patients regardless of endoscopic findings, two specimens were taken from the lower oesophagus, three from the gastric antrum, and four from the distal duodenum. One biopsy sample from all three sites was sent for histopathological and virological analysis. One specimen from the stomach and duodenum was sent for microbiological analysis, and one duodenal specimen was sent for mycobacterial culture.

\section{VIROLOGICAL METHODS}

Biopsy specimens were sent to virology in viral transport medium. The samples were homogenised and cultured on human embryonic lung fibroblasts. Detection of early antigenic fluorescent foci (DEAFF) was performed after 12 to 16 


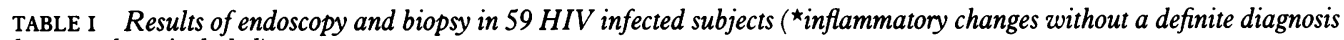
have not been included)

\begin{tabular}{|c|c|c|c|}
\hline$\underset{\substack{\text { Symptoms } \\
(n=59)}}{ }$ & $\begin{array}{l}\text { Endoscopic } \\
\text { diagnosis (no) }\end{array}$ & $\begin{array}{l}\text { Laboratory analysis } \\
\text { of biopsy specimens }{ }^{\star}(\text { no })\end{array}$ & Outcome (no) \\
\hline $\begin{array}{l}\text { Dysphagia heartburn or } \\
\text { retrosternal pain (18) }\end{array}$ & $\begin{array}{l}\text { Ulcers (3) } \\
\text { Candida (7) } \\
\text { HH (1) } \\
\text { Normal (7) }\end{array}$ & $\begin{array}{l}\text { CMV (3) } \\
\text { Candida (7) } \\
\text { CMV (1) } \\
\text { HLO (2) } \\
\text { No diagnosis (4) }\end{array}$ & $\begin{array}{l}\text { Ganciclovir-improved (3) } \\
\text { Fluconazole-improved (7) } \\
\text { Improved on ranitidine (1) } \\
\text { Acyclovir - improved (1) } \\
\text { Tonsil ulcer (1) } \\
\text { Gradual improvement (4) } \\
\text { Lost to follow up (1) }\end{array}$ \\
\hline Abdominal pain (14) & $\begin{array}{l}\text { GU (1) } \\
\text { GU and KS (1) } \\
\text { Candida (3) } \\
\text { Normal (9) }\end{array}$ & $\begin{array}{l}\text { CMV (1) } \\
\text { Candida (3) } \\
\text { CMV and villous atrophy (1) } \\
\text { HLO (5) } \\
\text { No diagnosis (3) }\end{array}$ & $\begin{array}{l}\text { Ganciclovir - improved (1) } \\
\text { Healed on ranitidine (1) } \\
\text { Candida improved (3) } \\
\text { No treatment (1) } \\
\text { CMV biliary sclerosis (1) } \\
\text { Triple therapy - improved (2) } \\
\text { HLO spon. improved (1) } \\
\text { Presumed gut vasculitis (1) } \\
\text { No diagnosis (2) } \\
\text { Gradual improvement (1) }\end{array}$ \\
\hline Dyspepsia (5) & Normal (5) & $\begin{array}{l}\text { Giardia (1) } \\
\text { HLO (1) } \\
\text { No diagnosis (3) }\end{array}$ & $\begin{array}{l}\text { Metronidazole - improved (1) } \\
\text { Giardia in stool (1) } \\
\text { ? splenomegaly (1) } \\
\text { Gradual improvement (1) } \\
\text { Lost to follow up (1) }\end{array}$ \\
\hline Diarrhoea (9) & $\begin{array}{l}\text { KS (1) } \\
\text { Candida (1) } \\
\text { Normal (6) }\end{array}$ & $\begin{array}{l}\text { Cryptosporidia and Candida (1) } \\
\text { Candida (1) } \\
\text { No diagnosis (5) }\end{array}$ & $\begin{array}{l}\text { Interferon for KS, but diarrhoea } \\
\text { persisted (1) } \\
\text { Cryptosporidia previously } \\
\text { diagnosed in stool } \\
\text { Candida improved (1) } \\
\text { Orange juice related (1) } \\
\text { Gradual improvement (2) } \\
\text { Persisting (1) } \\
\text { Lost to follow up (1) }\end{array}$ \\
\hline Vomiting (4) & $\begin{array}{l}\text { Candida (1) } \\
\text { Erosions (1) } \\
\text { Normal (2) }\end{array}$ & $\begin{array}{l}\text { CMV/Candida/papilloma virus } \\
\text { HLO (1) } \\
\text { No diagnosis (1) }\end{array}$ & $\begin{array}{l}\text { Treated for CMV/Candida } \\
\text { Indomethacin ceased } \\
\text { Alcohol related (1) } \\
\text { ? drug related (1) }\end{array}$ \\
\hline $\begin{array}{l}\text { Multiple symptoms (5) } \\
\text { Weight loss, vomiting, } \\
\text { dysphagia, PUO, abdominal } \\
\text { pain, diarrhoea }\end{array}$ & $\begin{array}{l}\text { Candida (2) } \\
\text { DU (1) } \\
\text { Normal (2) }\end{array}$ & $\begin{array}{l}\text { Candida (2) } \\
\text { HLO }(1) \\
\text { No diagnosis }(2)\end{array}$ & $\begin{array}{l}\text { Fluconazole - improved (1) } \\
\text { Caecal TB (1) } \\
\text { Died MAI within } 1 \text { month (1) } \\
\text { Died in intensive care (1) } \\
\text { HIV encephalopathy (1) }\end{array}$ \\
\hline $\begin{array}{l}\text { Miscellaneous } \\
\text { KS staging (2) } \\
\text { Anaemia (2) }\end{array}$ & $\begin{array}{l}\text { KS staged (2) } \\
\text { Normal (2) }\end{array}$ & $\begin{array}{l}\text { CMV (1) } \\
\text { (incidental) } \\
\text { HLO (1) }\end{array}$ & $\begin{array}{l}\text { KS treated (2) } \\
\text { Anaemia resolved (2) }\end{array}$ \\
\hline
\end{tabular}

$\mathrm{KS}=$ Kaposi's sarcoma, Candida $=$ candida oesophagitis, $\mathrm{CMV}=$ cytomegalovirus, $\mathrm{HLO}=$ Helicobacter pylori, $\mathrm{TB}=$ tuberculosis, $\mathrm{DU}=$ duodenal ulcer, $\mathrm{GU}=$ gastric ulcer, $\mathrm{PUO}=$ pyrexia of unknown origin, $\mathrm{MAI}=$ mycobacterium avium intracellulare, $\mathrm{HH}=$ hiatus hernia.

hours, to identify infection with cytomegalovirus. In addition, cultures were maintained for 21 days or until a positive result, whichever occurred first.

\section{MICROBIOLOGICAL METHODS}

Impression smears of specimens sent to microbiology were assessed microscopically by Auramine (cryptosporidium) and Giemsa (giardia) stains for ova, cysts, and parasites. They were then placed on Sabouraud's medium for yeasts and Robertson's cooked meat medium for bacterial pathogens; these cultures were read after 24 to 48 hours. Biopsy specimens sent for mycobacterial culture were placed on two Lowenstein-Jensen slopes, one supplemented with pyruvate and one with glycerol. Biopsy specimens were, in addition, cultured in Kirchner's broth.

\section{CYTOLOGICAL METHODS}

Brush cytology of the oesophagus was performed when candida was suspected endoscopically using a disposable sheathed endoscopic brush (Olympus, Keymed, Southend-on-Sea, Essex, UK). The brush was smeared onto four glass slides and fixed for five minutes in $74 \%$ industrial methylated spirits. The fixative was drained and the slides dried before Papanicolou staining for candida.

\section{Results}

The audit showed that a total of 69 endoscopies were performed in 59 patients over 24 months. Table I lists the endoscopic findings, laboratory results, and clinical outcome. Table II lists results of the laboratory analysis of the biopsy samples. The diagnostic yield of the biopsy procedures was much higher in patients with endoscopic disease (25/69 biopsies in 26 patients) than in those without endoscopic abnormality (4/43 in 33 patients excluding the presence of Helicobacter pylori). Of the four positive biopsy specimens in patients with a normal endoscopy, two had cytomegalovirus isolated, one had candida, and the last had giardia. Additionally two patients had unsuspected dual (Kaposi's sarcoma and CMV) and triple disease (cytomegalovirus, candida, and Papilloma virus). In only five of 26 patients with CDC stage II disease was a positive endoscopic appearance or laboratory result found (three of these had oesophageal candida seen at endoscopy, which proved to be their AIDS defining illness), while gastrointestinal abnormality (either on endoscopy or analysis of 
TABLE II Results of laboratory analysis of upper gastrointestinal mucosal biopsy specimens from 59 patients with HIV infection

\begin{tabular}{|c|c|c|c|c|c|}
\hline & Results (no) & $\begin{array}{l}\text { Total no } \\
\text { positive }\end{array}$ & $\begin{array}{l}\text { Total } \\
\text { specimens }\end{array}$ & $\begin{array}{l}\text { No of } \\
\text { positive } \\
\text { patients }\end{array}$ & Comments \\
\hline \multicolumn{6}{|l|}{ Virology } \\
\hline $\begin{array}{l}\text { DEAFF } \\
\text { culture }\end{array}$ & $\begin{array}{l}\text { CMV positive } \\
\text { CMV (3)+HSV (1) }\end{array}$ & $\begin{array}{l}6(10 \cdot 5 \%) \\
4(6 \cdot 7 \%)\end{array}$ & $\begin{array}{l}57 \\
60\end{array}$ & $\begin{array}{l}6 \\
4\end{array}$ & $\begin{array}{l}10 \text { specimens positive } \\
\text { in } 6 \text { patients }\end{array}$ \\
\hline \multirow{2}{*}{$\begin{array}{l}\text { Bacteriology } \\
\text { culture }\end{array}$} & & & & & \\
\hline & $\begin{array}{l}\text { Staphylococci (5) } \\
\text { Streptococci (5) } \\
\text { Miscellaneous (6) } \\
\text { (Candida, } \\
\text { enterococcus) }\end{array}$ & $16(13 \cdot 8 \%)$ & 116 & 16 & $\begin{array}{l}\text { Clinical significance } \\
\text { unclear (no giardia or } \\
\text { cryptosporidia seen) }\end{array}$ \\
\hline \multirow{2}{*}{$\begin{array}{r}\text { Histopathology } \\
\text { Oesophagus }\end{array}$} & & & & & \\
\hline & $\begin{array}{l}\text { Candida (5) } \\
\text { CMV (3) } \\
\text { CMV/Candida/ } \\
\text { papilloma virus (1) } \\
\text { Viral ulcers (2) }\end{array}$ & $11(21 \cdot 2 \%)$ & 52 & 11 & \\
\hline Stomach & $\begin{array}{l}\text { HLO (11) } \\
\text { Cryptosporidia (1) } \\
\text { KS (1) }\end{array}$ & $13(27 \cdot 7 \%)$ & 47 & 13 & $\begin{array}{l}\text { ? clinical significance } \\
\text { of HLO }\end{array}$ \\
\hline Duodenum & $\begin{array}{l}\text { CMV (1) } \\
\text { Cryptosporidia (1) } \\
\text { Giardia (1) } \\
\text { Villous atrophy (1) }\end{array}$ & $4(6 \cdot 2 \%)$ & 65 & 4 & $\begin{array}{l}\text { Total of } 28+ \\
\text { histopathology } \\
\text { abnormalities in } 25 \\
\text { patients }\end{array}$ \\
\hline \multicolumn{6}{|l|}{ Cytology } \\
\hline Oesophagus & Candida (14) & $14(82 \cdot 3 \%)$ & 17 & 14 & $\begin{array}{l}\text { Only performed when } \\
\text { candida suspected }\end{array}$ \\
\hline
\end{tabular}

$\mathrm{CMV}=$ cytomegalovirus, $\mathrm{HLO}=$ Helicobacter pylori, $\mathrm{KS}=$ Kaposi's sarcoma, $\mathrm{HSV}=$ herpes simplex virus, $\mathrm{DEAFF}=$ detection of early antigenic fluorescent foci.

the biopsy samples) was found in 21 of 30 AIDS patients. Cytomegalovirus infection was detected by virology DEAFF or culture in six of the 59 patients; histopathology detected a further two patients with cytomegalovirus infection, but failed to identify three of six who were positive by virological analysis. Brush cytology identified candida in $14 / 17(82 \cdot 3 \%)$ suspected cases, but only four of these patients had oral candida.

Microbiological analysis of endoscopic biopsy specimens grew gram positive or enteric flora from a minority of patients (Table II). Ova, cysts or parasites were not detected, and mycobacterial cultures were consistently negative. Histopathological analysis detected 27 abnormalities in the 59 patients - but in 11/47 gastric biopsy specimens the reported abnormality was the presence of $H$ pylori like organisms. Seven patients with CDC stage IV disease (six AIDS,

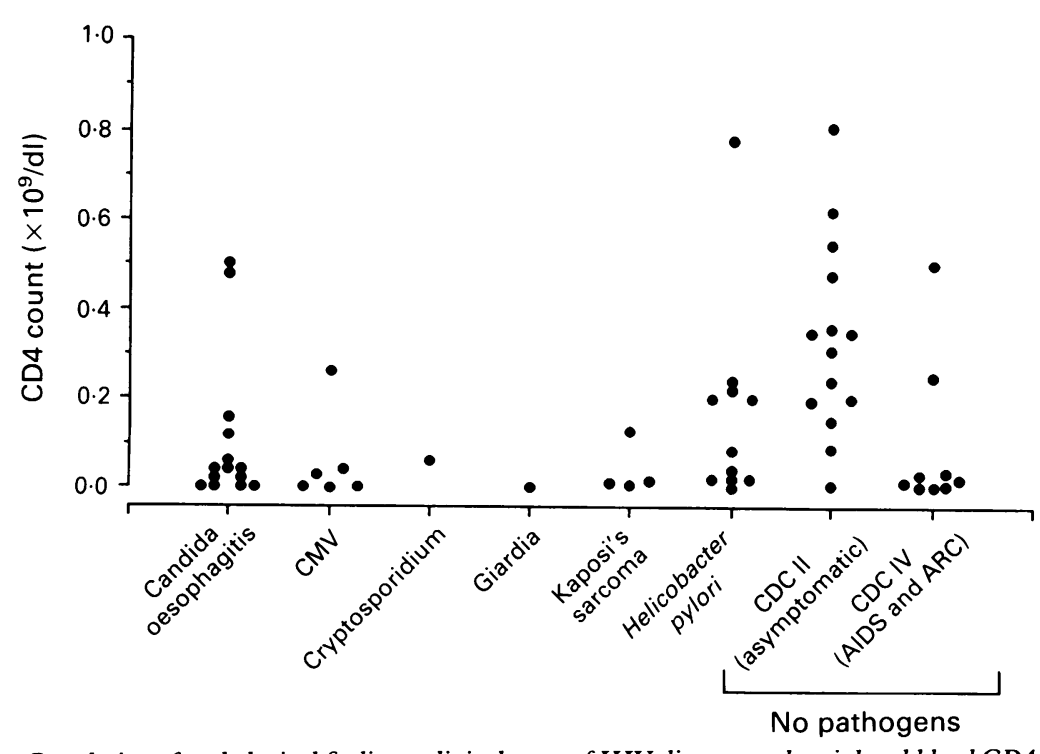

Correlation of pathological findings, clinical stage of $H I V$ disease, and peripheral blood CD4 count. $A R C=A I D S$ related complex. one ARC) and four CDC stage II (asymptomatic) had $H$ pylori.

The Figure relates the presence of abnormality either at endoscopy or on biopsy according to each patient's peripheral blood CD4 count. Almost all the patients with abnormal findings had a peripheral blood CD4 count less than $0 \cdot 2 \times 10^{6} / 1$; there were three exceptions: one had cytomegalovirus cultured from a small oesophageal ulcer, one had oesophageal candida infection after a splenectomy, and the third was found to have a few specks of candida confirmed on histology.

Two patients had cytomegalovirus cultured in the setting of a virtually normal endoscopy: the first patient had a small oesophageal ulcer when in CDC stage II and the second had cytomegalovirus cultured from a normal duodenal biopsy specimen. Neither patient received specific treatment for cytomegalovirus. On follow up, neither showed any overt cytomegalovirus disease, although the second patient soon died from other causes. The first patient is still free of clinical cytomegalovirus disease 22 months after the diagnostic endoscopy.

In all cases of positive endoscopic findings, pathological diagnosis played an important part in determining management. Other than confirming macroscopic findings, pathological diagnosis excluded cytomegalovirus in a gastric ulcer, permitted diagnosis of giardia infestation, and diagnosed dual (Kaposi's sarcoma and CMV) and triple (candida, CMV, and papilloma virus) disease in two patients.

\section{Discussion}

Our results show that upper gastrointestinal endoscopy is an important diagnostic procedure in patients with HIV infection. This is particularly true for patients with dysphagia or other oesophageal symptoms where $66 \%$ of endoscopies yielded a diagnostic result. This finding is in agreement with published works. ${ }^{7}$ While abdominal pain was a common indication for endoscopy, the diagnostic yield was lowreflecting the varied causes of abdominal pain.

Published studies have investigated the incidence of pathogens or pathology in AIDS patients, ${ }^{1347-9}$ and in particular AIDS patients with diarrhoea. ${ }^{510-12}$ This study, similar to previous studies, shows that there is a high incidence of disease in AIDS patients. Patients with asymptomatic HIV infection (CDC II), however, have a low incidence of disease on endoscopy or biopsy. Hence endoscopy without routine biopsies is sufficient for CDC II patients with high CD4 counts, unless endoscopic abnormalities are seen.

What is the clinical significance of $H$ pylori infection in an HIV infected patient? While 11/47 $(23.4 \%)$ patients who had antral biopsies were $H$ pylori positive, only seven had abdominal symptoms. None of the 11 patients had a duodenal ulcer, and the presence of $H$ pylori is probably an incidental finding. The prevalence of $H$ pylori in our study was somewhat higher at $24 \cdot 3 \%$ compared with previous reports of $4 \%^{13}$ and $14 \%{ }^{14}$ - which were considerably lower than in the normal 'healthy' population. Interestingly 
the Figure shows that almost all cases of $H$ pylori occurred in patients with CD4 counts $<0.3 \times$ $10^{9} / 1$, but only $6 / 11 \mathrm{H}$ pylori positive patients had AIDS. This seems to be at variance with Francis ${ }^{14}$ but, while our data suggest that $H$ pylori may increase with immunosuppression, this may be the result of the small population sample. The diagnostic success of endoscopic duodenal biopsy in patients with diarrhoea was low in this study; the most sensitive test remains stool analysis for pathogens and ova, cysts, and parasites, ${ }^{1-5}$ but if these are negative then additional sampling methods should be undertaken Crosby capsule biopsy, jejunal fluid sampling, brush cytology of jejunum to improve diagnostic yield.

There was no diagnosis of atypical mycobacteria either by histology or by biopsy culture despite the duodenum being the most common affected site. ${ }^{15}$ One of these patients died from disseminated atypical mycobacteria infection one month after his endoscopy, having had negative histopathology and duodenal culture for the bacterium.

Multiple biopsy specimens were taken to exclude occult cytomegalovirus infection as a potential cause of gastrointestinal symptoms. The findings of our study show that cytomegalovirus is unlikely to be discovered in the absence of visible pathology. Without mucosal pathology, a positive culture may be of dubious clinical significance, as shown by two patients who did not develop clinical cytomegalovirus disease despite having positive culture results. While attention has been focused on the potential for cytomegalovirus to cause abdominal pain, ${ }^{16}$ the diagnosis of cytomegalovirus disease remains difficult. Morphology remains the standard method of diagnosis, but there have been attempts to improve diagnosis by immunocytochemistry, electron microscopy, and viral culture. ${ }^{217}$ Unfortunately the detection of cytomegalovirus antigens (whether late or early) or virus in culture, shows the presence of the virus and not disease. Pathological infection with cytomegalovirus must remain a clinical or morphological diagnosis.

As a result of this audit, the clinical practice in management of HIV infected patients at upper gastrointestinal endoscopy has been changed at the Royal Free Hospital. Routine surveillance biopsies are no longer performed in those patients with CDC II disease or CD4 counts more than $0 \cdot 2 \times 10^{9} / 1$. Patients with diarrhoea remain an exception to this rule: they have more intensive investigations with culture, histology, electron microscopy, and brush cytology of the jejunal mucosa.

The authors would like to thank $\mathrm{Mr} \mathrm{O}$ Billington for processing specimens for mycobacterial culture, Mrs A Smith and Mr A Ramsey for processing parasitology specimens, and Dr Alastai Deery for reporting the cytology specimens.

1 Rene E, Marche C, Regneir B, Saimot AG, Vilde JL, Perrone $\mathrm{C}$, et al. Intestinal infections in patients with acquired immunodeficiency syndrome: a prospective study in 132 immunodeficiency syndrome: a prospect

2 Smith PD, Lane HC, Gill VJ, Manischewitz JF, Quinnan GV, Fauci AS, et al. Intestinal infections in patients with the acquired immunodeficiency syndrome. Ann Intern Med 1988; 108: 328-33.

3 Stamm B, Grant JW. Biopsy pathology of the gastrointestinal tract in human immunodeficiency virus-associated disease: 5 -year experience in Zurich. Histopathology 1988; 13 $531-40$

4 Sutherland LR, Church DL, Gill MJ, Kelly JK, Hwnag WS, Bryant HE. Gastrointestinal function and structure in HIV positive patients. Can Med Assoc f 1990; 143: 641-6.

5 Connolly GM, Forbes A, Gazzard BG. Investigation of seemingly pathogen negative diarrhoea in patients infected with ingly pathogen negative diar

6 MMWR. CDC revision of the CDC surveillance case definition for acquired immunodeficiency syndrome. MMWR 1987, 36: $1-15$

7 Connolly MG, Forbes A, Gleeson JA, Gazzard BG. Investigation of upper gastrointestinal symptoms in patients with AIDS. $A I D S$ 1989; 3: 453-6.

8 Bartelmans JF, Sara PR, Tytgat GN. Gastrointestinal complications in patients with acquired immunodeficiency. Scand $\mathcal{F}$ Gastroenterol 1989; 24: 112-7.

9 Edwards P, Wodak A, Cooper DA, Thompson IL, Penny R. The gastrointestinal manifestations of AIDS. Aust $N Z \mathcal{F}$ Med 1990; 20: 141-8.

10 Antony MA, Brandt LJ, Klein RS, Bernstein LH. Infectious diarrhoea in patients with AIDS. Dig Dis Sci 1988; 33: $1141-6$

11 Connolly GM, Shanson D, Hawkins DA, Harcourt Webster JN, Gazzard BG. Non-cryptosporidial diarrhoea in human mmunodeficiency virus (HIV) infected patients. Gut 1989 30: 195-200.

12 Greenson JK, Belitsos PC, Yardley JH, Bartlett JG. AIDS enteropathy; occult enteric infections and duodenal mucosa alterations in chronic diarrhoea. Ann Intern Med 1991; 114: 366-72.

13 Edwards PD, Carrick J, Turner J, Lee A, Mitchell H, Cooper DA. Helicobacter pylori-associated gastritis is rare in AIDS: antibiotic effect as a consequence of immunodeficiency. Am 7 Gastroenterol 1991; 86: 1761-4.

14 Francis ND, Logan RPH, Walker MM, Polson RJ, Boylston AW, Rinching AJ, et al. Campylobacter pylori in the upper GI tract of patients with HIV-1 infection. $\mathcal{F}$ Clin Pathol 1990 tract of patie

15 Gray JR, Rabeneck L. Atypical mycobacterial infection of the gastrointestinal tract in AIDS patients. Am $\mathcal{F}$ Gastroentero 1989; 784: $1521-4$

16 Gazzard BG. Practical advice for the gastroenterologist dealing with symptomatic HIV disease. Gut 1990; 31: 733-5.

17 Francis ND, Boylston AW, Roberts AH, Parkin JM, Pinching AJ. Cytomegalovirus infection in gastrointestinal tracts of patients infected with HIV-1 or AIDS. F Clin Pathol 1989; 42: $1055-64$. 